Jurnal Pariwisata Terapan Vol. 5., No. 2, 2021 ISSN-

2580-1031 (print) ISSN- 2580-104X (online)

https://jurnal.ugm.ac.id/jpt

\title{
Dampak Pengembangan Desa Wisata Wukirsari Terhadap Peningkatan Ekonomi Masyarakat Lokal Tahun 2017-2018
}

\author{
Putri Dwi Maryani ${ }^{1}$, Dr. Muchamad Zaenuri, M.Si. ${ }^{2}$ \\ Affiliation \\ ${ }^{1}$ Ilmu Pemerintahan, Universitas Muhammadiyah Yogyakarta \\ 2Ilmu Pemerintahan, Universitas Muhammadiyah Yogyakarta

\section{Correspodence} \\ Putri Dwi Maryani, Ilmu Pemerintahan, Universitas Muhammadiyah Yogyakarta, Jl. Brawijaya, \\ Geblagan, Tamantirto, Kec. Kasihan, Bantul, Daerah Istimewa Yogyakarta 55183. \\ Email:putridwimaryani13@gmail.com
}

\begin{abstract}
Wukirsari tourism village is an alternative tourism in Bantul Regency. By utilizing the diverse potential of Wukirsari Tourism Village, it is able to attract tourists to visit. In 2017, tourist arrivals reached 20,714 and in 2018 an increase in tourist arrivals reached 20,830. Increasing the number of visitors each year can increase the income of surrounding communities, especially those directly involved in the management of tourist villages. This study uses a descriptive qualitative approach so that it can provide a picture of the problem from the results of research in the field based on existing data. Data collection used in this study were observation, interviews, questionnaires, and documents.
\end{abstract}

Keywords: Tourism Village; Wukirsari; Economic Improvement; Lokal Community

Article Information:

Submitted 4 August 2020|Revised 16 February 2021|Accepted 13 August 2021

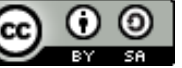

Copyright (C) 2021 by the author(s). This article is published by Universitas Gadjah Mada, Indonesia under the Creative Commons Attribution (CC BY 4.0) license. Anyone may reproduce, distribute, translate, and create derivative works of this article (for both commercial and noncommercial purposes), subject to full attribution to the original publication and author(s). The full terms of this license may be seen at http://creativecommons.org/licenses/by/4.0/legalcod 


\section{Pendahuluan}

Pariwisata merupakan salah satu sektor yang berkembang begitu pesat di Yogyakarta dan daerah sekitarnya. Banyaknya obyek-obyek wisata menjadi daya tarik tersendiri bagi wisatawan yang ingin menghabiskan waktu berlibur dengan menikmati suasana yang berbeda. Begitu banyaknya tempat-tempat wisata yang bisa dikunjungi mulai dari pusat perbelanjaan, wisata religi, wisata budaya, wisata edukasi hingga wisata alamnya yang mempesona siapa saja yang berkunjung. Selain itu berkembangnya sektor pariwisata harus didukung oleh berbagai fasilitas penunjang yang harus tersedia seperti alat transportasi dan penginapan yang bisa dengan mudah di akses.

Berkembangnya sektor pariwisata di Yogyakarta setiap tahunya berpengaruh terhadap tingkat kunjungan para wisatawan. Banyaknya wisatawan domestik maupun mancanegara yang berkunjung untuk berlibur tentunya memiliki dampak yang baik bagi perekonomian lokal. Masyarakat lokal dapat memanfaatkan kunjungan para wisatawan sebagai ladang untuk mencari nafkah. Terbukanya lapangan pekerjaan sebagai salah satu solusi mengurangi tingkat pengangguran dan dapat meningkatkan perekonomian masyarakat. Sektor pariwisata sampai saat ini memang menjadi andalan dan mempunyai nilai jual yang sangat besar di Yogyakarta dan diharapkan mampu mengangkat perekonomian.

Tabel 1. Jumlah Kunjungan Wisatawan Kabupaten/Kota di DIY Tahun 2018

\begin{tabular}{c|c|c} 
No. & Kabupaten/Kota di DIY & Jumlah Wisatawan \\
\hline 1. & Kota Yogyakarta & 4.752 .351 \\
\hline 2. & Kabupaten Sleman & 7.898 .088 \\
\hline 3. & Kabupaten Bantul & $\mathbf{8 . 8 4 0 . 4 2 2}$ \\
\hline 4. & Kabupaten Kulon Progo & 1.969 .623 \\
\hline 5. & Kabupaten Gunung Kidul & 3.055 .284
\end{tabular}

Sumber: Statistik Kepariwisataan DIY, 2018.

Berdasarkan tabel tersebut, dapat dilihat bahwa pengunjung Kabupaten Bantul sebagian besarnya dari wisatawan nusantara sebanyak 8.819.154 Sedangkan wisatawan mancanegara sebanyak 21.288. Jika diakumulasikan jumlah keseluruhan ada sebanyak 8.840.422 wisatawan yang mengunjungi Bantul sebagai salah satu destinasi wisata pilihan. Ini menunjukan bahwa eksistensi bantul sebagai tujuan wisatawan sangat diminati. Banyaknya obyek-obyek wisata yang ada di Bantul mempunyai daya tarik tersendiri, salah satu obyek wisata yang saat ini berkembang adalah Desa Wisata (Statistik Kepariwisataan DIY).

Munculnya obyek-obyek desa wisata maupun kampung wisata yang sedang menjamur di Yogyakarta dan sekitarnya menjadi salah satu fenomena tersendiri. Pada tahun 2017 sebanyak 131 obyek wisata dan pada tahun 2018 ada sebanyak 185 wisata obyek wisata yang meliputi wisata budaya, alam, buatan, desa wisata maupun kampung wisata (Statistik Kepariwisata DIY). Pemanfaatan potensi desa merupakan sebuah inovasi yang menguntungkan bagi masyarakat lokal. Trend desa wisata memang mempunyai daya tarik tersendiri di kalangan para wisatawan 
lokal maupun mancanegara. Para wisatawan yang berkunjung dapat menikmati suasana yang berbeda dalam berlibur dan mendapatkan edukasi yang bermanfaat. Setiap desa memiliki potensi yang berbeda-beda dalam mengelola desa wisata sesuai dengan ciri khasnya masingmasing. Oleh karena itu desa-desa maupun kampung-kampung di Kota Yogyakarta dan sekitarnya berlomba-lomba untuk mengelola potensi yang ada disekitarnya.

Potensi desa menjadi salah satu kunci dapat berkembangnya menjadi desa wisata. Partisipasi desa dalam meramaikan sektor pariwisata menjadi nilai lebih yang dapat menguntungkan perekonomian masyarakat lokal. Salah satu desa wisata yang ada di Kabupaten Bantul adalah Desa Wisata Wukirsari. Desa Wukirsari berada di Desa Wukirsari, Kecamatan Imogiri, Kabupaten Bantul. Desa Wukirsari mempunyai luas wilayah 15.385 .504 dan dengan jumlah penduduk sebanyak 17.245 dan terdapat 16 pedukuhan (Web Desa Wukirsari). Desa wisata Wukirsari memiliki berbagai potensi yang mendukung untuk dijadikan sebagai desa wisata. Sejak diresmikan sebagai desa wisata pada tahun 2010 desa wisata mulai berkembang hingga saat ini. Adanya kerajinan yang turun-temurun seperti pembuatan wayang kulit, batik tulis, kerajinan bambu, makam raja-raja dan wisata kuliner bisa menjadikan modal yang bagus untuk terbentuk nya desa wisata sebagai sustainable tourism development. Berdasar pada pemaparan diatas, penulis ingin lebih mendalami terkait "Dampak Pengembangan Desa Wisata Wukirsari Terhadap Ekonomi Masyarakat Lokal Tahun 2017-2018" menggunakan konsep desa wisata dan peningkatan ekonomi lokal.

\section{Konsep Desa Wisata}

Desa wisata adalah bentuk integrasi antara akomodasi, atraksi dan berbagai fasilitas yang mendukung untuk jalannya pariwisata yang direncanakan dengan terstruktur pada kehidupan masyarakat dan berbaur menjadi satu dengan tradisi yang berlaku pada desa tersebut (Nuryati, 1993: 2-3). Sedangkan pengertian desa wisata menurut Mulyawan (2008), desa wisata adalah desa yang memiliki daya tarik dan keunikan untuk dijadikan desa wisata. Memiliki lingkungan alam pedesaan dan keseharian yang menggambarkan kehidupan sosial dengan budaya kemasyarakatan.

Adapun syarat-syarat Pengembangan Desa Wisata Pearce (dalam Made dkk 2013), pengembangan desa wisata adalah suatu proses yang bertujuan untuk mengembangkan kemajuan desa wisata. Pengembangan desa wisata adalah usaha dalam meningkatkan dan melengkapi berbagai fasilitas-fasilitas wisata untuk memenuhi segala kebutuhan para wisatawan. Menurut Hadiwijoyo (dalam Septiofera 2016) ada beberapa syarat-syarat yang harus dipenuhi agar dapat dibentuknya sebuah desa wisata yaitu:

1. Mempunyai aksesbilitas yang baik.

2. Mempunyai obyek-obyek yang dapat menarik wisatawan.

3. Terdapat fasilitas yang dapat mendukung adanya desa wisata (tenaga kerja, akomodasi dan telekomunikasi).

4. Keamanan.

5. Masyarakat dan aparat sekitar yang mendukung dan menerima adanya desa wisata.

6. Berhubungan dengan obyek yang mudah diterima oleh masyarakat luas.

7. Beriklim sejuk. 


\section{Peningkatan Ekonomi Lokal}

Menurut Blakely dan Bradshaw dalam Nandang dkk, pengembangan ekonomi lokal suatu proses antara suatu organisasi masyarakat dan pemerintah lokal yang saling terlibat untuk memelihara, mendorong dan merangsang sebuah aktivitas yang dapat dikatakan sebagai usaha untuk menciptakan lapangan pekerjaan. Ekonomi lokal bisa dikatakan suatu proses pembentukan yang melibatkan kelembagaan baru. Dapat menghasilkan produk yang baik dan bermutu, munculnya usaha-usaha baru, pengembangan industri dan kapasitas pekerja. Sedangkan menurut, Helmsing (dalam Ghalib, 2015), yaitu suatu proses kerjasama pemerintah daerah, sektor swasta dan kelompok masyarakat untuk mengelola sumberdaya agar menciptakan lapangan pekerjaan baru guna memajukan perekonomian di daerah tertentu. Adanya pengendalian lokal dengan menggunakan potensi manusia, kemampuan fisik serta kelembagaan. Ekonomi lokal memiliki organisasi, sumber daya dan mengarahkan pelaku melalui tindakan strategis dan dialog.

Adapun dampak-dampak yang muncul akibat adanya desa wisata adalah sebagai berikut:

Menurut Pitana dan Gayatri 2005 (dalam Faizal Hamzah dkk, 2018), menyatakan dampak pariwisata selama ini diasumsikan bahwa datangnya wisatawan akan mempengaruhi bentuk sosial dan budaya sekitar, tiga asumsi tersebut adalah sebagai berikut:

1. Perubahan yang dibawa dari luar, sedangkan budaya yang menerima lebih lemah.

2. Perubahan destruktif bagi budaya yang menjadi tuan rumah.

3. Perubahan yang membawa hemogesi budaya, sehingga budaya tuan rumah akan tenggelam dengan budaya yang dibawa dari luar.

Sedangkan menurut Pitana 2009 mengemukkan bahwa ada 8 dampak pariwisata terhadap kondisi ekonomi yakni:

1. Penerimaan terhadap penerimaan devisa.

2. Dampak terhadap pendapatan masyarakat.

3. Dampak terhadap kesempatan kerja.

4. Dampak terhadap distribusi manfaat dan keuntungan.

5. Dampak terhadap kepemilikan dan kontrol ekonomi masyarakat.

6. Dampak pembangunan pada umumnya.

7. Dampak terhadap pendapatan pemerintah.

8. Dampak terhadap harga-harga.

\section{Metode}

\section{Pengumpulan Data}

a. Pengamatan dan Observasi

Dalam penelitian ini peneliti melakukan pengamatan dan observasi secara langsung ke obyek Desa Wisata Wukirsari, Imogiri Bantul untuk mendapatkan informasi yang mendalam.

b. Wawancara

Dalam penelitian ini peneliti melakukan wawancara ke beberapa pihak yang bersangkutan dalam penelitian ini yaitu: Kepala Desa Wukirsari, Pokdarwis, Pengelola Wisata, dan Masyarakat setempat untuk mendapatkan jawaban dari rumusan masalah.

c. Dokumentasi

Penelitian ini karena sebagian besar menginformasi-informasi yang didapatkan melalui beberapa dokumen yang sesuai dengan penelitian ini. 
Teknik Analisis Data

Menurut Sugiyono 2018, analisis data adalah suatu proses yang dilakukan dengan mencari dan menyusun secara terstruktur dari data yang telah diperoleh dari hasil catatan lapangan, dokumentasi maupun hasil wawancara dengan cara mengorganisasikan data tersebut ke dalam kategori kemudian menjabarkannya ke unit-unit dengan melakukan sintesa dan memilih yang penting dan yang akan dipelajari, yang terakhir membuat sebuah kesimpulan sehingga mudah untuk dipahami oleh diri sendiri maupun orang lain. Untuk itu suatu penelitian sangat diperlukan adanya analisis data yang berguna untuk memberikan jawaban terhadap permasalahan yang akan diteliti. Analisis data dalam penelitian ini menggunakan metode kualitatif. Analisa data adalah suatu proses yang mengatur urutan data mengorganisasikan ke dalam suatu pola, kategori dan satuan uraian yang dasar. Sedangkan metode kualitatif merupakan prosedur penelitian yang menghasilkan data deskriptif berupa kata-kata tertulis atau lisan dari data yang didapat. Dengan menggunakan metode Kualitatif, peneliti mendapatkan jawaban atas rumusan masalah sesuai dengan kondisi yang ada.

\section{Hasil dan Pembahasan}

Dampak Terhadap Masyarakat

Dampak terhadap pendapatan masyarakat merupakan salah satu indikator yang mengukur apakah masyarakat mendapatkan pendapatan yang lebih baik setelah adanya pengembangan Desa Wisata Wukirsari. Munculnya branding desa wisata sebagai berfungsi sebagai salah satu inovasi dalam pengelolaan pariwisata untuk meningkatkan kemandirian perekonomian desa. Dengan adanya branding tersebut apakah Desa Wisata Wukirsari mampu mengangkat perekonomian lokal. Berdasarkan penelitian, masyarakat Wukirsari memiliki beragam potensi yang mendukung dalam pengembangan desa wisata mulai dari wisata religi maupun buatan. Dengan memanfaatkan potensi-potensi yang ada secara maksimal dan pengelolaan yang baik maka akan mendapatkan dampak yang baik bagi masyarakat. Sejak adanya Desa Wisata Wukirsari masyarakat setempat mendapatkan berbagai keuntungan dari sektor perekonomian. Karena banyaknya jumlah wisatawan yang berkunjung setiap tahunnya berpengaruh terhadap pendapatan desa wisata yang secara langsung akan berpengaruh terhadap pendapatan masyarakat sekitarnya yang ikut terlibat langung dalam pengelolaan desa wisata selain itu mulai munculnya usaha-usaha mandiri yang didirikan masyarakat secara individu.

Tabel 2. Data Wawancara Terhadap Peningkatan Ekonomi Lokal

\begin{tabular}{c|c|c|c} 
No. & $\begin{array}{c}\text { Wawancara } \\
\text { (Masyarakat, } \\
\text { Pengelola Wisata } \\
\text { dan Pengerajin) }\end{array}$ & $\begin{array}{c}\text { Mengalami } \\
\text { Peningkatan }\end{array}$ & $\begin{array}{c}\text { Tidak Mengalami Peningkatan } \\
\text { (Biasa Saja) }\end{array}$ \\
\hline 1. & 30 Orang & 26 & 4
\end{tabular}

Sumber: Diolah, 2020.

Untuk membuktikan bahwa masyarakat Wukirsari mengalami peningkatan ekonomi peneliti melakukan wawancara terhadap 30 orang, sebanyak 26 orang yang menyatakan mengalami peningkatan dan 4 orang sisanya merasa biasa-biasa saja. Dengan begitu masyarakat Wukirsari 
tidak sepenuhnya mengalami peningkatan pendapatan sejak adanya pengembangan desa wisata. Dan berdasarkan data diatas seluruh masyarakat, pengrajin maupun pengelola wisata merasakan adanya dampak peningkatan ekonomi.

Sebesar $86 \%$ masyarakat Wukirsari mengalami peningkatan, dalam pengelolaan desa wisata yang paling diuntungkan adalah para pengrajin karena mereka dapat ikut berpartisipasi mengelola obyek wisata agar mendapatkan penghasilan tambahan dan juga pekerjaan pokok mereka sebagai pengrajin yang menghasilkan kerajinan sehingga bisa diperjual belikan di tempat wisata tersebut maupun disortir oleh pelanggan mereka dengan adanya branding desa wisata masyarakat merasakan dampak yang menguntungkan untuk mereka karena dapat meningkatkan pendapatan mereka dengan menjual paket wisata sehingga diperlukan pendampingpendamping dari para pengrajin untuk melatih secara singkat dalam membuat batik maupun wayang dan pedagang-pedagang jajanan dari dalam maupun luar Desa Wukirsari mempunyai kesempatan untuk menjajakan dagangannya jika ada wisatawan yang berkunjung jadi bukan hanya masyarakat Wukirsari saja yang diuntungkan namun orang-orang luar juga mempunyai kesempatan untuk mendapatkan keuntungan selain itu usaha-usaha galeri milik perorangan juga terkena dampak, karena banyak dari wisatawan yang berbelanja oleh-oleh untuk dijadikan souvenir. Dari beberapa aspek yang telah diteliti masyarakat Wukirsari yang berpartisipasi dalam pengembangan Desa wisata mengalami peningkatan pendapatan.

Tabel 3. Jumlah Pengunjung Desa Wisata Wukirsari

\begin{tabular}{c|c|c} 
No. & Tahun & Jumlah Pengunjung \\
\hline 1. & 2017 & $\mathbf{2 0 7 1 4}$ \\
\hline 2. & 2018 & $\mathbf{2 0 8 3 0}$
\end{tabular}

Sumber: Pengelola Desa Wisata.

Dengan meningkatnya jumlah kunjungan setiap tahun akan berdampak terhadap peningkatan pendapatan masyarakat sekitar obyek wisata. Karena dengan adanya desa wisata, masyarakat dapat ikut berpartisipasi dalam pengelolaan sehingga, terutama yang bekerja sebagai pengrajin, dapat memanfaatkan SDM nya untuk menjadi pendamping wisata. Selain itu munculnya usahausaha baru seperti galeri kerajinan milik pribadi maupun warung juga dapat mengangkat perekonomian, sehingga hal ini diharapkan mampu memajukan perekonomian lokal. Pemerintah Daerah dan Pemerintah Desa mendukung jalannya pengembangan desa wisata dengan tidak memungut pajak desa wisata. Sehingga kepemilikan dan kontrol ekonominya pure milik masyarakat yang bersama-sama membangun desa wisata dengan asas gotong-royong. Jadi berdasarkan pembahasan di atas bahwa dengan adanya pengembangan desa wisata input dan output kembali ke masyarakat sehingga masyarakat dapat merasakan dampak peningkatan, terlebih dampak ekonomi.

Dampak Terhadap Kesempatan Kerja

Pemanfaatan dari dampak adanya pengembangan desa wisata ini juga secara tidak langsung menumbuhkan kesadaran masyarakat sekitar untuk memunculkan ide-ide dalam 
mengembangkan usahanya sendiri. Selain itu pedagang-pedagang dari luar juga dapat masuk untuk menjajakan dagangannya saat ada pengunjung yang datang. Adanya sebuah desa wisata sebenarnya bukan hanya memberi kesempatan kerja masyarakat lokal saja, namun juga masyarakat luar yang menjajakan dagangannya juga mendapatkan keuntungannya. Sehingga juga dapat memberikan kesempatan kerja bagi siapa saja bukan hanya masyarakat yang berpartisipasi langsung saja dalam pengelolaan Desa Wisata Wukirsari.

Tabel 4. Usaha-Usaha yang Muncul Sejak Pengembangan Desa Wisata Wukirsari

Sumber: Diolah, 2020.

\begin{tabular}{c|l} 
No. & \multicolumn{1}{|c}{ Usaha-usaha yang muncul } \\
\hline 1. & Homestay \\
\hline 2. & Warung \\
\hline 3. & Pedagang kaki lima \\
\hline 4. & Showroom \\
\hline 5. & Kuliner "Pasar Sor Jati" \\
\hline 6. & Catering
\end{tabular}

Masyarakat Wukirsari mempunyai hak yang sama dalam berpartisipasi pengelolaan desa wisata ini. Masyarakat dapat ikut menjual hasil produksinya di showroom galeri yang sudah disediakan oleh pengelola desa wisata. Mereka juga dapat membuka usaha-usaha galeri mandiri maupun warung-warung makan disekitar tempat wisata dan masyarakat sekitar juga dapat membuka homestay jika ada pengunjung yang akan menginap sehingga dapat menambah penghasilan mereka dengan menyewakan kamar sehingga masyarakat sekitar mendapatkan dampak yang sama.

Berdasarkan data di atas, ada beberapa usaha yang muncul sejak adanya desa wisata yaitu munculnya pengelolaan homestay oleh masyarakat sekitar jika ada wisatawan yang ingin menginap ataupun memesan paket menginap. Banyaknya usaha warung-warung yang ada disekitar yang menjual kebutuhan pokok dan adanya pedagang kaki lima yang berdatangan jika ada wisatawan yang berkunjung untuk menjual berbagai dagangannya. Dan adanya showroom untuk para pengrajin batik maupun wayang menjual hasil kerajinanya ke pengunjung yang berkunjung sehingga mempermudah pengunjung yang ingin berbelanja souvenir-souvenir hasil produksi masyarakat setempat. Seiring berjalanya waktu, pemuda-pemudi Wukirsari mulai ikut berpartisipasi dalam memberikan ide untuk membuat obyek wisata baru yaitu Pasar Sor Jati adalah tempat wisata kuliner yang dikelilingi pohon-pohon jati yang baru ada tahun 2019. Dengan semakin bertambahnya obyek wisata yang muncul maka semakin besar pula kesempatan kerja yang ada.

Dampak pengembangan desa wisata terhadap kesempatan kerja di Desa Wukirsari yaitu, masyarakat sekitar obyek wisata mendapatkan kesempatan dalam mengelola desa wisata bersama sesuai dengan kemampuan SDM masing-masing. Sehingga mulai dari pemuda-pemuda hingga bapak-bapak mendapatkan hak yang sama. Terutama para pengrajin yang mendapatkan pekerjaan tambahan menjadi pendamping wisata di saat ada pengunjung. Maka dari itu dengan adanya desa wisata dapat menyerap pengangguran masyarakat lokal. Selain masyarakat yang 
turut berperan aktif dalam mengelola obyek wisata dan para pengrajin yang memanfaatkan keahliannya untuk menjadi pemandu wisata untuk mendapatkan keuntungan dengan jalannya pariwisata yang ada. Masyarakat awam sekitar pun juga dapat membuka lapangan pekerjaan untuk orang-orang sekitar maupun membuka usaha untuk dirinya sendiri dengan membuka warung ataupun toko. Sehingga dengan adanya desa wisata tersebut, yang sebenarnya diuntungkan adalah masyarakat sekitar, karena adanya pengembangan desa wisata memang untuk mengembangkan perekonomian kemandirian desa.

\section{Dampak Pembangunan Pada Umumnya}

Dalam pembangunannya Desa Wisata Wukirsari sudah baik dalam melakukan pembangunan terutama akses jalan yang berfungsi sebagai penghubung antar daerah. Untuk penerangan lampu jalan juga sudah cukup memadai. Masyarakat sekitar merasakan dampak yang muncul akibat adanya desa wisata seperti pembangunan jalan yang semakin hari semakin baik, sehingga selain adanya dampak terhadap pendapatan mereka juga merasakan adanya pembangunan yang semakin membaik. Karena dengan adanya hal ini, mempermudah masyarakat sekitar dalam mencari uang untuk memenuhi kebutuhan pokok.

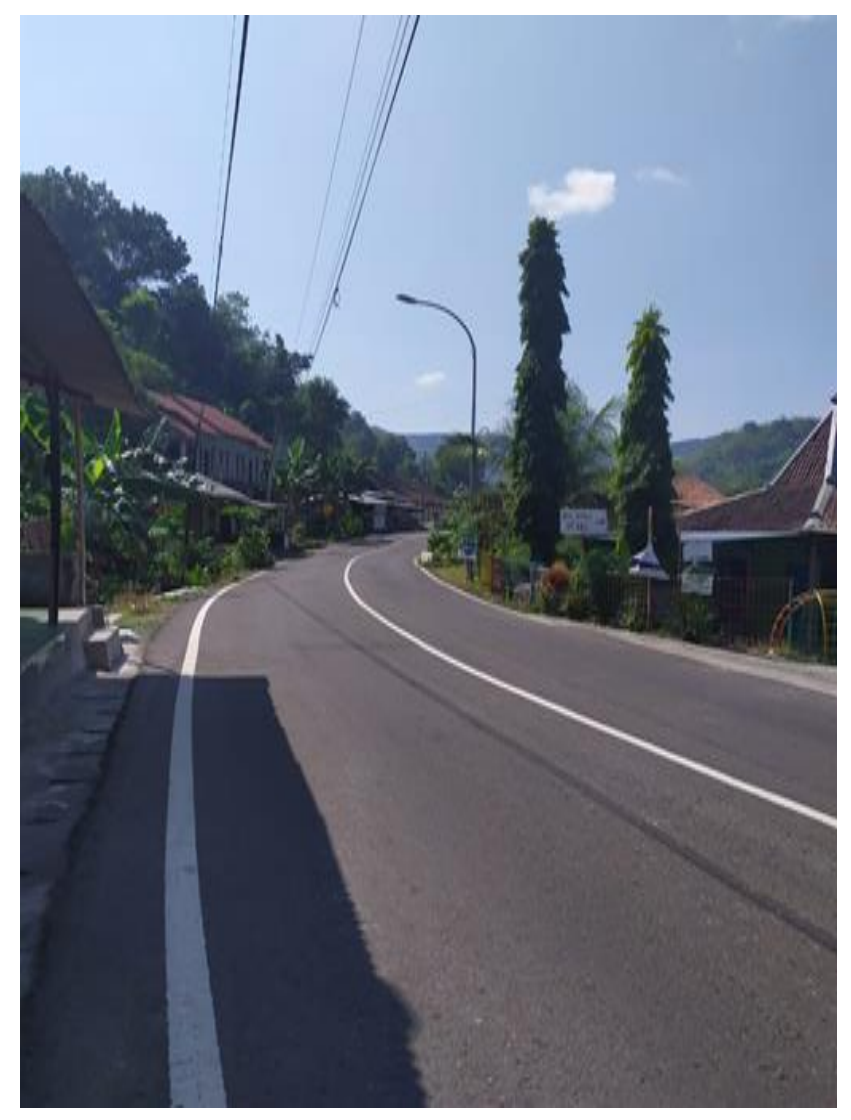

Gambar 1. Kondisi Jalan Utama Desa Wukirsari

(Sumber: Dokumnetasi, 2020)

Desa Wisata Wukirsari juga memiliki fasilitas-fasilitas yang baik guna memenuhi kebutuhan pengunjung. Fasilitas-fasilitas tersebut dibangun untuk memaksimalkan pengembangan desa 
wisata agar mempermudah pengelola menjalankan desa wisata tersebut. Agar pengunjung merasa nyaman dan senang saat berwisata tentunya fasilitas-fasilitas yang ada harus lengkap dan dalam kondisi yang baik. Karena salah satu komponen penting dalam mengelola desa wisata adalah adanya fasilitas yang memadai.

Tabel 5. Fasilitas Desa Wisata

Sumber: Diolah, 2020.

\begin{tabular}{l|l|c} 
No. & \multicolumn{1}{|c|}{ Fasilitas } & Kondisi \\
\hline 1. & Gazebo & Baik \\
\hline 2. & Tempat Parkir & Baik \\
\hline 3. & Toilet Umum & Baik \\
\hline 4. & Terminal Wisata & Baik \\
\hline 5. & Tempat Ibadah & Baik \\
\hline 6. & Showroom & Baik \\
\hline 7. & Homestay & Baik \\
\hline 8. & Ruko & Baik \\
\hline 9. & Workshop & Baik \\
\hline 10. & Internet & Kurang Baik
\end{tabular}

Berdasarkan data diatas, fasilitas-fasilitas penunjang desa wisata dalam keadaan baik. Dan dapat digunakan sesuai dengan fungsinya masing-masing, namun ada beberapa fasilitas yang perlu ditambah lagi dan terus diperbaiki agar dapat memaksimalkan fasilitas yang ada. Hanya saja perlunya pembangunan tempat ibadah yang memadai di dekat obyek wisata.

Dampak pembangunan pada umumnya, dalam pembangunan Desa Wisata Wukirsari sudah baik dan akan terus melakukan pembangunan jika diperlukan untuk menunjang desa wisata agar pengunjung betah untuk berlama-lama di obyek wisata. Masyarakat sangat diuntungkan dengan pembangunan fasilitas-fasilitas desa seperti akses jalan yang sudah baik. Lalu untuk menunjang obyek wisata yang ada, terus dilakukan perbaikan yang diperlukan untuk melengkapi fasilitas wisata. Untuk kedepannya ada beberapa fasilitas-fasilitas yang memang harus dipenuhi seperti pembangunan tempat ibadah di sekitar obyek wisata agar pengunjung tidak harus berjalan jauh. Dengan adanya pengembangan desa wisata, masyarakat Wukirsari merasakan dampak terhadap pembangunan yang ada. Karena pada intinya mereka juga memanfaatkan fasilitas yang ada di desa tersebut. Diharapkan dengan adanya pembangunan-pembangunan yang dilakukan dapat mempermudah masyarakat dalam hal ekonomi.

\section{Dampak Terhadap Distribusi Manfaat dan Keuntungan}

Keuntungan yang didapatkan masyarakat dari ikut dalam berpartisipasinya pengembangan desa wisata mendatangkan manfaat. Masyarakat dapat menjual hasil kerajinannya maupun souvenirsouvenir dengan mudah memasarkannya. Di desa Wukirsari sendiri memiliki sebuah showroom yang berfungsi untuk memajang berbagai hasil kerajinan untuk dijual. Untuk memperlancar pemasaran desa wisata diperlukan usaha-usaha untuk mengembangkan tingkat penjualan tiket maupun produk. Sehingga masyarakat yang bekerja sebagai pengrajin mempunyai peluang baru di sektor wisata. 
Tabel 6. Mata Pencaharian Masyarakat Wukirsari

\begin{tabular}{c|c|c|c} 
No. & Jenis Pekerjaan & Jumlah & Satuan \\
\hline 1 & LINMAS & 76 & Jiwa \\
\hline 2 & Pengrajin & 829 & Jiwa \\
\hline 3 & Swasta & 1.261 & Jiwa \\
\hline 4 & PNS & 233 & Jiwa \\
\hline 5 & Pedagang & 1.133 & Jiwa \\
\hline 6 & Tukang & 730 & Jiwa \\
\hline 7 & TNI/POLRI & 57 & Jiwa \\
\hline 8 & Dokter/Perawat/Bidan & 730 & Jiwa \\
\hline 9 & Petani & 1.344 & Jiwa
\end{tabular}

Sumber: Profil Desa Wukirsari, 2019.

Banyaknya para pengrajin di Desa Wukirsari hingga mencapai 829 jiwa menempati urutan ke 4 dari mata pencaharian masyarakat Wukirsari mengharuskan adanya wadah untuk para pengrajin dalam mendistribusikan hasil produksinya. Selain para pengrajin yang memang sudah mempunyai langganan untuk di salurkan hasil produksinya, ada juga pengrajin yang membuat sovenir kecil-kecil yang dijual sebagai cinderamata. Oleh karena itu, untuk menarik wisatawan agar berkunjung di Desa Wisata Wukirsari, pengelola desa wisata telah merencanakan manajemen pemasaran dan promosi. Dengan adanya promosi-promosi yang dilakukan dengan bekerjasama dengan berbagai pihak dapat mendorong Desa Wisata Wukirsari dikenal masyarakat luas sebagai salah satu destinasi desa wisata yang ada di Kabupaten Bantul, sehingga masyarakat kalangan luas mengetahui dan datang berkunjung maupun berbelanja. Selain bekerjasama dengan berbagai pihak, Desa Wisata Wukirsari juga mempunyai strategi pemasaran online marketing yang mempermudah dalam pemasarannya. Dan para pengrajin dapat memasarkan hasil produksinya dengan mudah bukan hanya offline namun juga bisa online sehingga peluang dalam penjualnya juga cukup besar.

Tabel 7. Strategi Pemasaran dan Promosi

\begin{tabular}{c|l} 
No. & \multicolumn{1}{c}{ Strategi Pemasaran } \\
\hline 1. & Showroom bersama yang terletak di Sentra Batik Giriloyo \\
\hline 2. & $\begin{array}{l}\text { Bergabung dengan berbagai event pameran (Lokal, Nasional dan } \\
\text { Internasional) }\end{array}$ \\
\hline 3. & $\begin{array}{l}\text { Bekerjasama dengan Tour Agency, jaringan hotel dan pariwisata untuk } \\
\text { membawa tamu berkunjung dan berbelanja ke Giriloyo }\end{array}$ \\
\hline 5. & $\begin{array}{l}\text { Online Marketing } \\
\text { Kengadakan berbagai event tahunan desa seperti (Festival Gunungan, } \\
\text { dan Festival Batik). }\end{array}$
\end{tabular}

Sumber: Pengelola Paguyuban Batik, 2020.

Dengan adanya sistem strategi pemasaran dan promosi telah menguntungkan para pengrajin untuk mendistribusikan hasil kerajinannya. Dengan terus diadakannya promosi untuk kalangan 
luar, diharapkan dapat dan mampu menarik wisatawan untuk berkunjung maupun sekedar berbelanja kerajinan yang ada di Desa Wukirsari. Selain memanfaatkan semaksimal mungkin SDM yang ada, desa wisata Wukirsari juga ikut melakukan pameran lokal hingga internasional guna untuk mempromosikan Wukirsari sebagai desa wisata. Karena adanya sistem tersebut masyarakat sekitar dapat merasakan dampak secara langsung yakni dagangan dan kerajinan mereka laku terjual lebih banyak dibanding sebelumnya adanya desa wisata maupun online marketing.

Dampak terhadap manfaat dan keuntungan distribusi dengan melakukan kerjasama dengan lembaga luar dalam berpromosi telah meningkatkan pengunjung terbukti dengan meningkatnya pengunjung setiap tahunnya. Dengan mengatur pemasaran untuk menjual hasil produksi pun juga baik karena pengelola dapat memanfaatkan kesempatan yang ada dalam menjual hasil-hasil produksi dan dengan adanya online marketing yang dikelola juga dapat meningkatkan penjualan produk kerajinan para perajin. Selain itu masyarakat sekitar juga dapat menjual dagangannya dengan mudah, karena pengunjung seringkali memborong dagangan mereka sehingga masyarakat merasakan dampak yang positif.

Selain bekerjasama dengan pihak luar untuk berpromosi, Desa Wisata Wukirsari juga mempromosikan sendiri desanya dengan melakukan event tahunan untuk menarik wisatawan untuk datang seperti Festival Gunungan, Kirab Budaya, Nyadran, Pertunjukan Seni Rutin, Expo Desa, Lelang Batik dan Festival Batik. Sehingga seluruh masyarakat dapat ikut berpartisipasi dan bergotong-royong dalam pembangunan desa wisata. Sehingga dengan adanya desa wisata ini mereka terwadahi terutama para pengrajin, karena mereka mendapatkan kesempatan untuk menjual hasil produksinya dengan mudah. Jadi pada intinya, dengan adanya desa wisata masyarakat mendapatkan manfaat dan keuntungan, dikelola oleh masyarakat lokal dan hasilnya untuk masyarakat lokal juga.

\section{Kesimpulan}

Berdasarkan Penelitian yang telah dilakukan tentang Dampak Adanya Desa Wisata Wukirsari Terhadap Peningkatan Ekonomi Masyarakat Lokal Tahun 2017-2018 dapat disimpulkan bahwa dengan adanya pengembangan Desa Wisata telah mempengaruhi kondisi ekonomi masyarakat lokal Wukirsari terutama dampak terhadap pendapatan masyarakat sekitar. Sejak adanya pengembangan desa wisata, masyarakat dapat memperbaiki kondisi perekonomian dengan munculnya jenis-jenis usaha baru dan terbuka lapangan pekerjaan sebagai pendamping wisata. Dengan adanya gagasan ini, diharapkan menjadi upaya pemerintah setelah dapat menekan jumlah pengangguran lingkup lokal Desa Wukirsari dan terus mewujudkan upaya mengembangkan desa dengan memaksimalkan potensi yang ada di masyarakat. Begitu pula dampak pembangunan yang terus dilakukan dengan baik untuk menunjang fasilitas desa wisata. Peran Pemerintah Desa dalam membantu pengembangan desa wisata sudah cukup baik dengan meminjamkan tanah kas desa untuk memperluas kebutuhan obyek wisata. 


\section{Daftar Pustaka}

\section{Buku}

Sugiyono. 2018. Metode Penelitian Kuantitatif, Kualitatif dan R\&D. Bandung: Alfabeta.

Jurnal

Al-Kautsari, M. M. (2017). Model Transisi Peningkatan Partisipasi Masyarakat Desa: Strategi Pengembangan Usaha Industri Kreatif Kerajinan Batik di Desa Krebet Kabupaten Bantul. Jurnal Pemberdayaan Masyarakat: Media Pemikiran dan Dakwah Pembangunan, 1(1), 1936.

Andayani, A. A. I., Martono, E., \& Muhamad, M. (2017). Pemberdayaan Masyarakat Melalui Pengembangan Desa Wisata Dan Implikasinya Terhadap Ketahanan Sosial Budaya Wilayah (Studi Di Desa Wisata Penglipuran Bali). Jurnal Ketahanan Nasional, 23(1), 1-16.

Besra, E. (2015). Potensi wisata kuliner dalam mendukung pariwisata di kota Padang. JRAB: Jurnal Riset Akuntansi \& Bisnis, 12(1).

Cahyono, A. E., \& Putra, Y. B. T. (2017). ANALISIS POTENSI EKONOMI PENGEMBANGAN AGROWISATA BERBASIS KEARIFAN LOKAL DI DESA WISATA SUMBERMUJUR KABUPATEN LUMAJANG. ECo-Socio: Jurnal ilmu dan Pendidikan Ekonomi, 1(1), 14-22.

Dewi, M. H. U. (2013). Pengembangan desa wisata berbasis partisipasi masyarakat lokal di Desa Wisata Jatiluwih Tabanan, Bali. Jurnal Kawistara, 3(2).

Hamzah, F., Hermawan, H., \& Wigati, W. (2018). Evaluasi Dampak Pariwisata Terhadap Sosial Ekonomi Masyarakat Lokal. Jurnal Pariwisata, 5(3), 195-202.

Hani'ah, J. (2017). Peran Pokdarwis Pancoh dalam Meningkatkan Partisipasi Masyarakat Sebagai Upaya Pengembangan Desa Wisata Pancoh, Turi, Sleman. Jurnal Elektronik Mahasiswa Pend. Luar Sekolah-S1, 6(6), 628-639.

Kusniawati, D., Islami, N. P., Setyaningrum, B., \& Prasetyawati, E. (2017). Pemberdayaan masyarakat berbasis potensi lokal melalui program desa wisata di Desa Bumiaji. Sosioglobal: Jurnal Pemikiran dan Penelitian Sosiologi, 2(1), 59-72.

MANDAR, K. P., \& ALFIRA, R. (2014). IDENTIFIKASI POTENSI DAN STRATEGI PENGEMBANGAN EKOWISATA MANGROVE PADA KAWASAN SUAKA MARGASATWA MAMPIE DI KECAMATAN WONOMULYO.

Prafitri, G. R., \& Damayanti, M. (2016). Kapasitas Kelembagaan Dalam Pengembangan Desa Wisata (Studi Kasus: Desa Wisata Ketenger, Banyumas). Jurnal Pengembangan Kota, 4(1), 76-86.

Polnaya, G. A., \& DARWANTO, D. (2015). Strategi Pengembangan Ekonomi Lokal Untuk Meningkatkan Daya Saing Pada Ukm Ekonomi Kreatif Batik Bakaran Di Pati, Jawa Tengah (Doctoral dissertation, Fakultas Ekonomika dan Bisnis).

Prabowo, S. E., Hamid, D., \& Prasetya, A. (2016). Analisis partisipasi masyarakat dalam pengembangan desa wisata (studi pada Desa Pujonkidul Kecamatan Pujon Kabupaten Malang). Jurnal Administrasi Bisnis, 33(2), 18-24.

Purmada, D. K., \& Hakim, L. (2016). Pengelolaan Desa Wisata Dalam Perspektif Community Based Tourism (Studi Kasus pada Desa Wisata Gubugklakah, Kecamatan Poncokusumo, Kabupaten Malang). Jurnal Administrasi Bisnis, 32(2), 15-22.

Setiawan, I. B. D., \& Budiarta, I. P. (2017). Strategi Pengembangan Desa Bongkasa Pertiwi Kabupaten Badung Sebagai Desa Wisata. SOSHUM: Jurnal Sosial dan Humaniora [Journal of Social Sciences and Humanities], 7(1), 12-22. 
Sidik, F. (2015). Menggali potensi lokal mewujudkan kemandirian desa. JKAP (Jurnal Kebijakan dan Administrasi Publik), 19(2), 115-131.

Sidiq, A. J., \& Resnawaty, R. (2017). Pengembangan desa wisata berbasis partisipasi masyarakat lokal di desa wisata Linggarjati Kuningan, Jawa Barat. Prosiding Penelitian dan Pengabdian kepada Masyarakat, 4(1), 38-44.

Sekaran, U. (2009). Bougie. M," Research Methods for Business: A Skill Building Approach". UK: John Wiley \& Sons.

Tajudin, J., (2018). Strategi Pengembangan Desa di Mangunan dalam Meningkatkan Pendapatan Asli Desa (PADES) Desa Mangunan, Kecamatan Dlingo, Kabupaten Bantul. Skripsi, Fakultas Ilmu Pemerintahan Universitas Muhammadiyah Yogyakarta. Yogyakarta.

Tisnawati, E., \& Ratriningsih, D. (2017). PENGEMBANGAN KONSEP PARIWISATA SUNGAI BERBASIS MASYARAKAT; Studi Kasus: Kawasan Bantaran Sungai Gadjah Wong Yogyakarta.

Ratu, C., \& Adikampana, I. M. (2016). Strategi Pemasaran Desa Wisata Blimbingsari Kabupaten Jembrana. Jurnal Destinasi Pariwisata, 4(1), 60-67.

Ridwan, M., Fatchan, A., \& Astina, I. K. (2016). Potensi Objek Wisata Toraja Utara Berbasis Kearifan Lokal Sebagai Sumber Materi Geografi Pariwisata. Jurnal Pendidikan: Teori, Penelitian, dan Pengembangan, 1(1), 1-10.

\section{Web}

https://jogjacars.com/wisata-jogja/desa-wisata-wukirsari-bantul https://visitingjogja.com/19962/statistik-pariwisata-diy-2018/

Data, B. J. D. S., Data, C. T. P., \& Data, D. T. A. (1997). A. Rancangan Penelitian. 